\title{
Production of ROS and its effects on mitochondrial and nuclear DNA, human spermatozoa, and sperm function
}

\author{
Hardi Darmawan
}

\begin{abstract}
Abstrak
Selama beberapa puluh tahun terakhir, banyak peneliti mempelajari penyebab-penyebab infertilitas pria, yang difokuskan pada peranan spesies oksigen reaktif (SOR). Spesies oksigen reaktif adalah suatu zat pengoksidasi yang sangat reaktif dan tergolong dalam kelompok radikal bebas. Bila kadar SOR meningkat, maka terjadi stres oksidatif yang menghasilkan oksigen dan oksidan derivat oksigen, yang pada gilirannya meningkatkan kerusakan sel. Pada manusia, SOR diproduksi oleh beberapa komponen semen, dan antioksidan pada cairan seminalis akan menjaga keseimbangan kadar SOR tersebut. Fungsi SOR dalam jumlah sedikit akan membantu kemampuan fertilisasi spermatozoa. Banyak penelitian menunjukkan bahwa SOR menyerang integritas DNA pada nukleus sperma dengan cara modifikasi basa, memutuskan untai DNA, dan menyebabkan “chromatin cross linking”. Kerusakan DNA meningkatkan kadar SOR dan dapat mempercepat proses apoptosis sel germinal yang berakibat menurunnya jumlah sperma yang berkaitan dengan kasus infertilitas pria. Makalah ini menelaah asal molekular/selular SOR pada semen, bagaimana SOR merusak DNA nukleus sperma, dan bagaimana kerusakan DNA berperanan dalam infertilitas pria. Peningkatan produksi SOR oleh spermatozoa berkaitan dengan penurunan potensial membran mitokondria (PMM), yang merupakan indikator penting untuk integritas fungsional spermatozoa. Apoptosis sel germinal penting untuk fungsi spermatogenesis normal dan gangguan regulasinya akan mengakibatkan infertilitas pria. Pemahaman penyebab dan mekanisme apoptosis sel germinal merupakan hal penting dalam mencegah masalah reproduksi pria. Tingkat apoptosis pada spermatozoa matang yang berkorelasi secara signifikan dengan kadar SOR cairan seminalis yang ditentukan oleh pemeriksaan kemiluminesens menunjukkan adanya hubungan antara SOR dan masalah fertilitas. (Med J Indones 2007; 16:127-33)
\end{abstract}

\begin{abstract}
Over the past few decades many researchers studying the causes of male infertility have recently focused on the role played by reactive oxygen species (ROS) - highly reactive oxidizing agents belonging to the class of free radicals. If ROS levels rise, oxidative stress (OS) occurs, which results in oxygen and oxygen derived oxidants, and in turn increases the rates of cellular damage. In human, ROS are produced by a variety of semen components, and antioxidants in the seminal fluid keep their level balance. Small amounts of ROS help spermatozoa acquire their necessary fertilizing capabilities. Many researches showed that ROS attack DNA integrity in the sperm nucleus by causing base modification, DNA strand breaks, and chromatin cross linking. The DNA damage induced excessive levels of ROS and might accelerate the process of germ cell apoptosis leading to a decline in sperm counts associated with male infertility. This paper will review the molecular (cellular) origins of ROS in human semen, how ROS damage sperm nuclear DNA, and how such DNA damage contributes to male infertility. Increased ROS production by spermatozoa is associated with a decreased mitochondrial membrane potential (MMP), which is an important indicator of functional integrity of the spermatozoa. Germ cell apoptosis is essential for normal spermatogenesis and its dysregulation may lead to male infertility. Thus, understanding the causes and mechanisms of germ cell apoptosis is of major importance in preventing male reproductive problems. Levels of apoptosis in mature spermatozoa that were significantly correlated with levels of seminal ROS determined by chemiluminescence assay indicate the linkage between ROS and male fertility problems. (Med J Indones 2007; 16:127-33)
\end{abstract}

Keywords: Apoptosis, infertility, free radicals

Oxidative stress $(\mathrm{OS})$ is a condition associated with an increased rate of cellular damage induced by oxygen and oxygen-derived oxidants called reactive oxygen

Department of Physiology, Faculty of Medicine, University of Sriwijaya, Palembang, Indonesia species (ROS). ${ }^{1}$ The susceptibility of human spermatozoa to OS has been suggested as a cause of male infertility. $^{2,3}$ At low levels, ROS mediate normal sperm function such as capacitation, hyperactivation, acrosomal reaction, and sperm-oocyte fusion, but at high levels, the increased production of ROS can cause OS and induce pathophysiological changes in the 
spermatozoa. The principal means of ROS-mediated injury to spermatozoa are peroxidative damage to the cell membrane and oxidative damage to mitochondrial DNA, causing impairment of sperm motility. ${ }^{4}$ High levels of seminal ROS have been reported in $20 \%$ $40 \%$ of infertile men. Increased understanding of the role of OS in the pathophysiology of human spermatozoa is imperative in the study of human infertility. This paper will review the molecular (cellular) origins of ROS in human semen, how ROS damage sperm nuclear DNA, and how such DNA damage contributes to male infertility.

\section{REACTIVE OXYGEN SPECIES AND OXIDATIVE STRESS}

Reactive oxygen species are highly reactive oxidizing agents belonging to the class of free radicals. A free radical is any compound (not necessarily derived from oxygen) which contains one or more unpaired electrons. The most common ROS that have potential implications in reproductive biology include the superoxide $\left(\mathrm{O}_{2}^{-}\right)$anion, hydrogen peroxide $\left(\mathrm{H}_{2} \mathrm{O}_{2}\right)$, peroxyl $\left(\mathrm{ROO}^{-}\right)$radicals, and the very reactive hydroxyl $\left(\mathrm{OH}^{-}\right)$radicals. The nitrogen derived free radical nitric oxide (NO) and peroxynitrite anion $\left(\mathrm{ONOO}^{-}\right)$also appear to play a significant role in the reproduction and fertilization. The ultimate effects of NO depend upon its concentration and interactions with hydrogen peroxide. Peroxynitrite (oxoperoxynitrate) anion may be formed in vivo from superoxide and nitric oxide and actively reacts with glutathione, cystein, deoxyribose, or other thiols/thioethers. ${ }^{5}$ Thus it can form strongly nitrating species in the presence of metal ions or complexes. "Free radicals" can influence male fertility. The mechanism of loss of sperm function involved OS due to excessive generation of ROS. However, small amounts of ROS are needed for sperm physiology.

\section{Reactive oxygen species (ROS) and sperm physiology}

Reactive oxygen species were once exclusively considered toxic to human spermatozoa. However, a strong body of evidence suggests that small amounts of ROS are necessary for spermatozoa to acquire fertilizing capabilities. ${ }^{6}$ The idea that limited amounts of ROS can physiogically regulate somatic sperm functions was first evoked by a study. ${ }^{7}$ In the study, they observed that ROS, at low levels, enhanced the ability of human spermatozoa to bind zonae pellucida, an effect that was reversed by the addition of vitamin
E. As a general rule, incubating spermatozoa with low concentrations of hydrogen peroxide $\left(\mathrm{H}_{2} \mathrm{O}_{2}\right)$, stimulates sperm capacitation, hyperactivation, and the ability of the spermatozoa to undergo a cross reaction and fusion with oocyte. Reactive oxygen species other than $\mathrm{H}_{2} \mathrm{O}_{2}$, such as nitric oxide and peroxide anion $\left(\mathrm{O}_{2}^{-}\right)$, have also been shown to promote sperm capacitation and acrosome reaction. ${ }^{8}$

\section{CELLULAR ORIGIN OF ROS IN SEMEN}

Morphologically abnormal spermatozoa and seminal leucocytes have been established as the main sources of ROS production in human ejaculates. Virtually every human ejaculate is contaminated with potential sources of ROS, subjecting some sperm cells to oxidative damage that causes concomitant loss of function. Thus, the impact of OS on male infertility is a question of the degree of OS rather than a pathological condition.

\section{ROS production by spermatozoa}

Spermatozoa may generate ROS in two ways:

- The nicotinamide adenine dinucleotide phosphate (NADPH) oxidase system at the sperm plasma membrane.

- Nicotinamide adenine dinucleotide (NADH) dependent oxido-reductase (diphorase) at mitochondria. The mitochondrial system is the major source and target of ROS in spermatozoa in infertile men. ${ }^{9}$ Spermatozoa are rich in mitochondria because they need a constant supply of energy for their motility. Production of ROS is significantly increased in dysfunctional mitochondria, which in turn affects mitochondrial function in spermatozoa. Such a relationship could be due to two mutually interconnected phenomena - ROS cause damage to the mitochondrial membrane, and the damaged mitochondrial membrane causes an increase in ROS production. Mitochondria contain a double membrane. The outer membrane allows large molecules to flow into the inter membrane space, and the highly invaginated inner membrane, which has a large surface area, is responsible for oxidative phosphorylation. During the process of oxidative phosphorylation the protons are pumped from inside the mitochondrion to the outside, creating an electro chemical gradient called the inner mitochondrial membrane potential (MMP). 
- The ability to discriminate between mitochondria exhibiting high membrane potential from those having low MMP provides a rigorous estimate of their metabolic function, and serves as an indicator of functional integrity of spermatozoa. Wang at al. ${ }^{10}$ showed that mitochondrial function as measured by MMP was decreased in the spermatozoa of infertile men with elevated levels of ROS and was positively correlated with sperm concentration.

\section{ROS production by seminal leukocytes}

Activated leukocytes are capable of producing $100-$ fold higher amounts of ROS than non-activated leukocytes. Leukocytes may be activated in response to a variety of stimuli including inflammation and infection. ${ }^{11}$ Activated leukocytes increase NADPH production via the hexose monophosphate shunt. The myeloperoxidase system of both PMN leukocytes and macrophages is also activated, which leads to respiratory burst and production of high levels of ROS. Such an oxidative burst is an early and effective defense mechanism for killing the microbes in cases of infection. Sperm damage from ROS that is produced by leukocytes occurs if seminal leukocytes concentrations are abnormally high, if the patient has epididymitis, or if seminal plasma was removed during sperm preparation for assisted reproduction. However, it is observed that seminal leukocytes may induce oxidative stress even at concentration below the WHO cut off for leukocytospermia (i.e. $<1 \times 10^{6}$ peroxidase positive leukocytes/ $\mathrm{ml}$ semen). ${ }^{12}$ This may be due to the fact that seminal plasma contains large amounts of ROS scavengers, but confers a variable (10\% to $100 \%)$ protection against ROS generated by leukocytes. ${ }^{13}$

\section{ROS SCAVENGING STRATEGIES IN SEMEN}

Oxidative stress was defined several years ago as the disequilibrium between pro-oxidative and anti-oxidative agents in a complex biological system, where the pro-oxidative agents (oxidants) overrode the antioxidative agents (anti-oxidants) (Figure 1). Oxidative molecular compounds, namely ROS, are produced primarily by the physiological metabolism of $\mathrm{O}_{2}$ in cells in aerobic conditions. These molecules are highly reactive to some cellular structures, thus reduce or eliminate the biological functions and properties of those structures.
Cells in a biological environment (such as ejaculate) contribute to the maintenance of the oxidative homeostasis via various systems, that results in controlled level of ROS necessary for the normal functioning of the cells.

This control depends on antioxidant molecules which are grouped into two classes depending on their nature: enzymatic and non-enzymatic. Seminal plasma contains enzymatic antioxidants, such as superoxide dismutase (SOD), glutathione peroxidase (GPX), glutathione reductase (GRD) and catalase, as well as non-enzymatic antioxidants, such as ascorbinate, urate, ${ }^{14}$ vitamin $\mathrm{E}$ (alpha tocopherol pyruvate), lactate, glutathione, epinephrine, taurine and hypotaurine. ${ }^{15}$

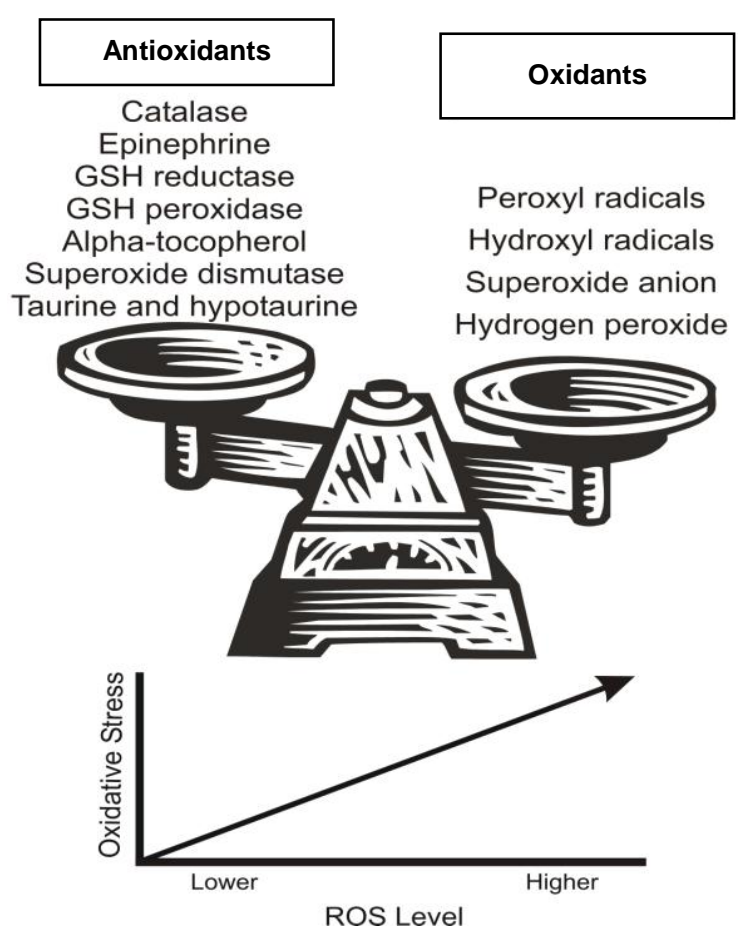

Figure 1. Oxidative stress: imbalance between oxidants and anti-oxidants

Seminal plasma from fertile men has a higher total antioxidant capacity than that of infertile men. ${ }^{16}$ However pathological levels of ROS detected in semen from infertile men are more likely due to increased ROS production rather than reduced antioxidant capacity of the seminal plasma. ${ }^{17}$ In addition to antioxidants, fight against increased ROS and oxidative damage is effected via defense mechanisms that include three levels of protection: prevention, interception, and repair. 


\section{Prevention}

Prevention of ROS formation is the first line of defense against oxidative damage. An example is the binding of metal ions, iron and copper ions in particular, which prevents them from initiating a chain reaction. When transition metals become loosely bound to biological molecules such as oxygen reduction products, they can produce secondary and more reactive oxidants, particularly $\mathrm{OH}^{-}$. Thus, chelation of transition metals is a major means of controlling lipid peroxidation and DNA damage.

\section{Interception}

Free radicals have a tendency toward chain reaction, e.g. a compound carrying an unpaired electron will react with another compound to generate an unpaired electron, "radical begets radical". Hence, the basic problem is to intercept a damaging species from further activity, which is the process of deactivation leading to the formation of non-radical end products. Vitamin E ( $\alpha$ tocopherol), a chain breaking antioxidant, inhibits lipid peroxidation in membrane by scavenging peroxyl $\left(\mathrm{ROO}^{-}\right)$and alcoxyl radicals<smiles>[R]C(=C)[O-]</smiles>

The ability of $\alpha$ tocopherol to maintain a steady state rate of radical reduction in the plasma membrane depends on the recycling of $\alpha$ tocopherol by external reduction against a substrate such as ascorbate or thiol. In this way, $\alpha$ tocopherol can function again as a free radical chain breaking antioxidant even though its concentration is low. A prerequisite for efficient interception is a relatively long half life of the radical to be intercepted. The peroxyl radicals are major reaction partners because their half-life extends into the range of second (7s). In contrast, the hydroxyl radical, with its high reactivity and extremely short half-life $\left(10^{-9} \mathrm{~s}\right)$, cannot be intercepted with reasonable efficiency.

\section{Repair}

Protection from an oxidant effect can also occur by repairing the damage once it has occurred. Unfortunately, spermatozoa are unable to repair the damage induced by ROS because they lack the cytoplasmic enzyme systems that are required to accomplish this repair. This is one of the features that make spermatozoa unique in their susceptibility to oxidative insult. ${ }^{18,19}$

\section{CORRELATION BETWEEN SPERM ROS PRODUCTION AND SPERM MORPHOLOGY}

A significant negative correlation was observed between sperm ROS production and the proportion of sperm with normal and borderline morphology. Reactive oxygen species production was positively correlated with the proportion of sperm with amorphous heads, damaged acrosomes, midpiece defects, cytoplasmic retention (Figure 2 and 3), tail defects, and sperm deformity index (SDI) scores. ${ }^{20,21}$

\section{SPERMATOZOA MITOCHONDRIALDNA DAMAGE}

Spermatozoa mitochondrial DNA $\left(\mathrm{M}_{\mathrm{t}} \mathrm{DNA}\right)$ abnormalities consist of deletions, point mutations and polymorphism. These abnormalities have been associated with a decline in semen quality, motility and male fertility. Mitochondrial DNA lacks histones, which help protect against damage. Furthermore, it is believed that $\mathrm{M}_{t}$ DNA only has basic repair mechanisms. A study revealed that populations of human spermatozoa exhibiting evidence of mitochondrial dysfunction showed high rates of nuclear DNA fragmentation. Moreover, abnormal sperm samples revealed high incidence of $\mathrm{M}_{\mathrm{t}}$ DNA damage, which suggested their role in male infertility. ${ }^{22}$

Normal sperm Defective sperm

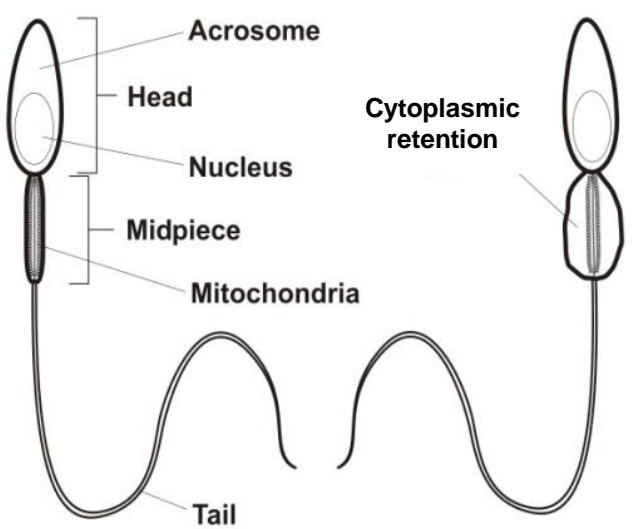

Figure 2. Schematic representation of a normal mature spermatozoon (left), and a defective spermatozoon showing cytoplasmic retention in the mid-piece 


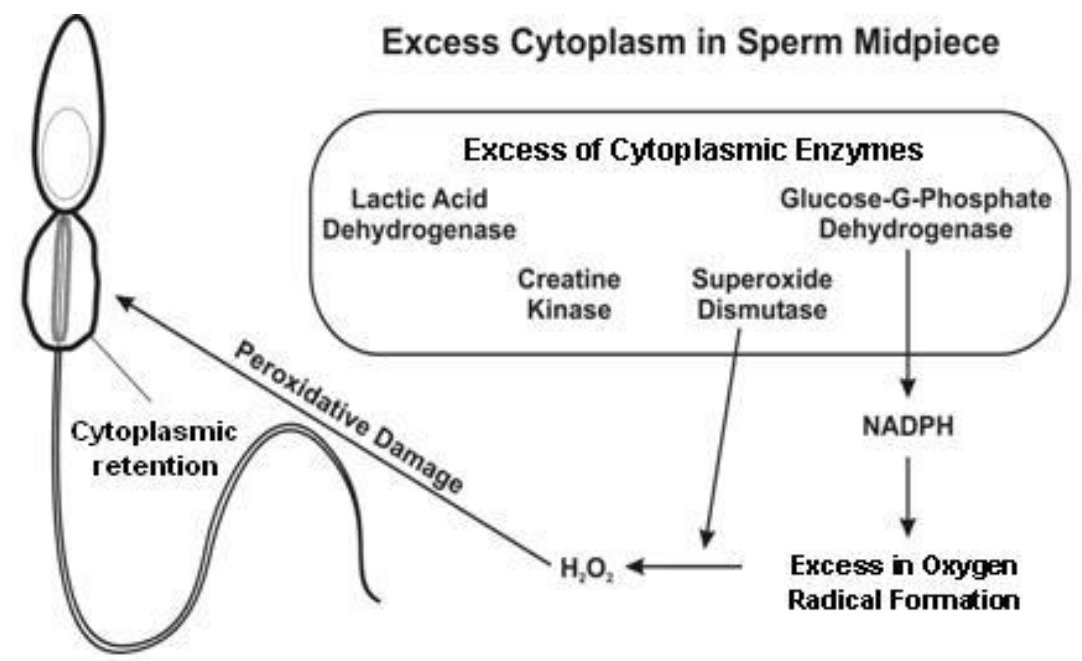

Figure 3. Mechanism of increased production of ROS by an abnormal spermatozoon with cytoplasmic retention ${ }^{20}$

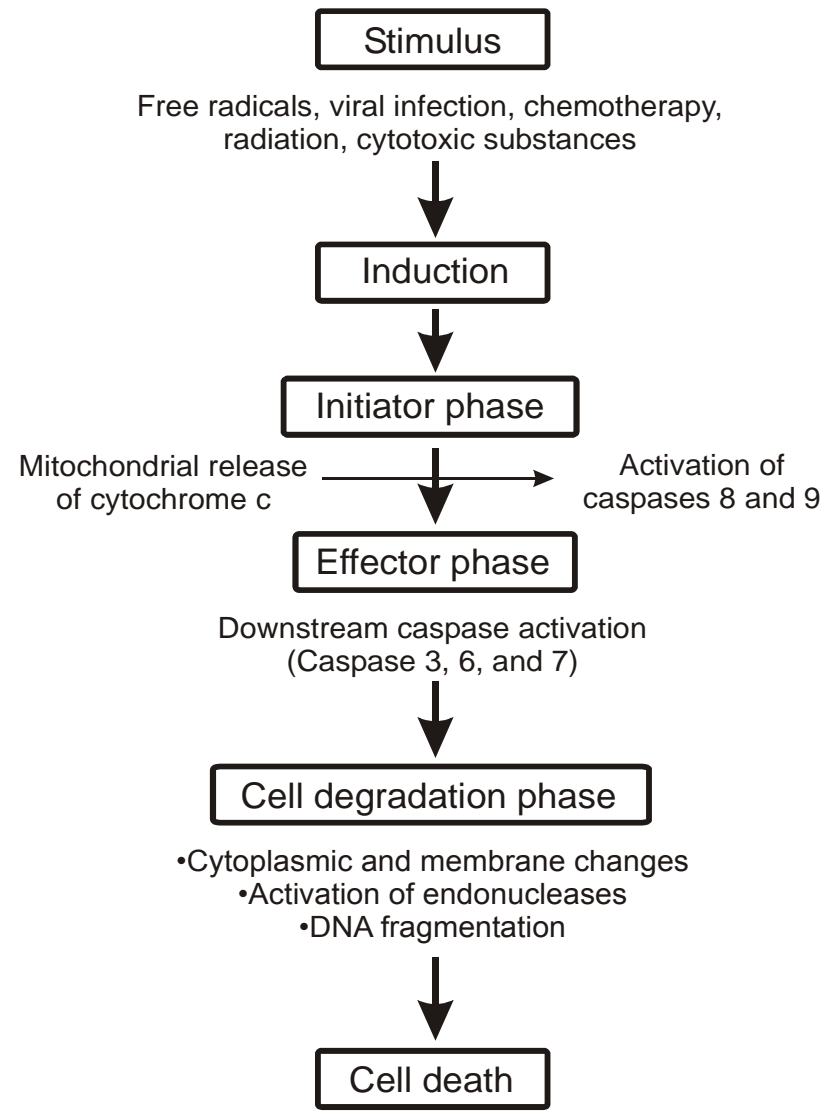

Figure 4. The process of apoptosis in human cells 


\section{SPERMATOZOA NUCLEAR DNA DAMAGE}

Anomalies in the nucleus of ejaculated spermatozoa had been found in several studies. The extent of DNA damage was closely related to sperm function and male infertility. Different mechanisms have been proposed to explain the presence of these anomalies in human ejaculate. Three factors suggested to be the cause of DNA damage in the germ line are: oxidative stress, deficiencies in natural processes such as improper chromatin packaging and ligation during sperm maturation, and abortive apoptosis. ${ }^{23}$

\section{Oxidative stress}

Oxidative stress is caused by an imbalance between the production of ROS and the antioxidant capacity. Spermatozoa have two defense mechanisms against oxidative attack on their DNA: the packaging arrangement of the DNA and the anti oxidants in seminal plasma. Reactive oxygen species cause a significant increase in DNA damage by modification of all bases, production of base free sites, chromatin DNA crosslinking, DNA strand breaks, DNA base oxidation, chromosomal deletions, frameshift, dicentrics and sister chromatid exchanges and chromosomal rearrangements. ${ }^{24}$ Oxidative stress was also showed to be correlated with apoptosis and high frequencies of single and double DNA strand breaks. Furthermore, the increased levels of specific forms of oxidative damage products such as 8-hydroxydeoxyguanosine in sperm DNA support such a theory. ${ }^{23}$

\section{Improper sperm chromatin packaging}

Immature spermatozoa that show high levels of DNA damage and ROS production are likely to have alterations in protamination and chromatin packaging. This fact is supposed to play a role in the suceptibility to DNA framentation. The DNA fragmentation is characterized by single and double strand DNA breaks, which are often detected in ejaculates of subfertile men. Double stranded breaks may also occur naturally in the male germ line in preparation for recombination and during the process of chromatin packaging. These physiological strand breaks are normally resolved in the spermatid stage of spermatogenesis.

\section{Apoptosis}

Apoptosis, also described as programmed cell death, is a physiological phenomenon characterized by cellular morphological and biochemical alteration leading to cell suicide. Apoptosis may be responsible for controlling overproduction of male gametes,${ }^{25}$ and restriction of normal proliferation levels so that they do not surpass the supportive capacity of Sertoli cells. ${ }^{26}$ Testicular germ cell apoptosis occurs normally and continuously throughout life and occurs in the testes during spermatogenesis as a result of endonuclease activation. This occurs predominantly in the spermatogonia and dividing cells and generates numerous DNA strand breaks in chromatin. The presence of endogenous DNA nicks in ejaculated spermatozoa is characteristic of abortive programmed cell death as seen in apoptosis of somatic cells. The ROS are known inducers of apoptosis in somatic and testicular sperm cells. However, it is not clear whether ejaculated sperm are able to initiate an apoptotic process in response to external stimuli such as high levels of ROS. An increased number of sperm expressing apoptotic markers has been observed during inflammatory processes in the male genital tract. This might be associated with increased ROS levels, which are not only part of the antibacterial defensive mechanism of inflammatory cells during infection, but also cause tissue damage and impairment of membranes and sperm DNA (Figure 4).

It has been demonstrated that the loss of phospholipids asymmetry, leading to the release of phosphatidyl serine (PS) to the outside of the plasma membrane, is an early event of apoptosis. As the anticoagulant annexin $\mathrm{v}$ binds to negatively charged phospholipids, such as $\mathrm{PS}$, and conjugated annexin $\mathrm{v}$ binds to fluorescein isothiocyanate, it is possible to use this marker for identification of apoptotic cells. ${ }^{7}$ One factor that plays a role in sperm apoptosis is the cell surface protein Fas. Fas is a type I membrane protein that belongs to the tumor necrosis factor - a nerve growth factor receptor family that mediates apoptosis. Binding of Fas ligand (Fas-L) or agonistic anti-Fas antibody to Fas kills cells by apoptosis.

In conclusion, recent experimental evidence in many research centers demonstrated that low and controlled concentrations of ROS played an important role in sperm physiology and more precisely, in the acquisition of fertilizing ability. Reactive oxygen species were involved in sperm hyperactivation, capacitation and acrosome reaction and lead to defining these processes as oxidative or redox regulated. While certain levels of ROS increase vital sperm functions, excessive concentrations of ROS cause sperm pathology.

Spermatozoa and leukocytes seem to be the sources of ROS. The fine balance between ROS production and scavenging are of paramount importance for the 
acquisition of fertilizing ability by spermatozoa and hence male fertility in general.

\section{REFERENCES}

1. Pardon OF, Brackett NL, Sharma RK, Kohn S, Lynne C.M, Thomas AJ Jr, et al. Seminal reactive oxygen species, sperm motility, and morphology in men with spinal cord injury. Fertil Steril. 1997; 67:1115-20.

2. Aitken RJ, Clarkson JS. Cellular basis of defective sperm function and its association with the genesis of reactive oxygen species by human spermatozoa. J Reprod Fertil. 1987; 81:459-69.

3. Purvis K, Christeansen E. The impact of infection on sperm quality. J British Fertil Soc. 1995; 1:31-41.

4. de Lamirande E, Gagnon C. Impact of reactive oxygen species on spermatozoa: A balancing act between beneficial and detrimental effects. Hum Reprod. 1995; 10:15-21.

5. de Lamirande E, Gagnon C. Human sperm hyperactivation and capacitation as parts of an oxidative process. Free Radic Biol Reprod. 1993; 40:183-97.

6. Kovalski NN, de Lamirande E, Gagnon C. Reactive oxygen species generated by human neutrophils inhibit sperm motility: protective effects of seminal plasma and scavengers. Fertil Steril. 1992; 58:809-16.

7. Aitken RJ. The Amoroso Lecture. The human spermatozoon- a cell in crisis? J Reprod Fertil. 1999; 115:1-7.

8. de Lamirande, Jiang H, Zini A, Kodama H, Gagnon C. Reative oxygen species and sperm physiology. Reviewers of Reproduction. 1997; 2:48-54.

9. Plante M, de Lamirande E, Gagnon C. Reactive oxygen species released by activated neutrophils, but not by deficient spermatozoa, are sufficient to affect normal sperm motility. Fertil Steril. 1994; 62:387-8.

10. Wang X, Sharma RK, Sikka SC, Thomas AJ Jr, Falcone $\mathrm{T}$, Agarwal A. Oxidative stress is associated with increased apoptosis leading to spermatozoa DNA damage in patients with male factor infertility. Fertil Steril. 2003; 80:531-5

11. Pasqualotto FF, Sharma RK, Kobayashi H, Nelson DR, Thomas AJ Jr, Agarwal A. Oxidative stress in normospermic men undergoing infertility evaluation. J Androl. 2001; 73:459-64.

12. Sharma R, Pasqualotto FF, Nelson DR, Thomas AJ Jr, Agarwal A. Relationship between Seminal white blood cell counts and oxidative stress in men treated at an infertility clinic. J Androl. 2001; 22:575-83.

13. Baker HW, Brindle J, Irvine D S, Aitken RJ. Protective effect of antioxidants on the impairment of sperm motility by activated polymorphonuclear leukocytes. Fertil Steril. 1996;65(2):411-9.

14. Thiele JJ, Freisleben HJ, Fuchs J, Oshendorf FR. Ascorbic acid and urate in human seminal plasma: determination and interrelationship with chemiluminescence in washed semen. Hum Reprod. 1995; 10:110-5.

15. Alvarez JG, Storey BT. Taurine, hypotaurine, epinephrine and albumin inhibit lipid peroxidation in rabbit spermatozoa and protect against loss of motility. Biol Reprod. 1983; 29:548-55.

16. Garrido N, Mesequer M, Simon C, Pellicer A, Remohil J. Pro-oxidative and anti - oxidation imbalance in human semen and its relation with male fertility. Asian J Androl. 2004; 6:59-65.

17. Zini A, de Lamirande E, Gagnon C. Reactive oxygen species in the semen of infertile patients: levels of superoxide dismutase - and catalase-like activities in seminal plasma. Int J Androl. 1993; 16: 183-8.

18. Sikka S, Hellstrom W. Role of oxidative stress and antioxidants in male infertility. J Andrology. 1995; 16:464-8.

19. Saleh RA, Agarwal A, Kandirali E, Sharma RK, Thomas AJ Jr, Nada EA, et al. Leukocytospermia is associated with increased reactive oxygen species production by human spermatozoa. Fertil Steril. 2002; 78:1215-24.

20. Saleh RA, Agarwal A. Oxidative stress and male infertility from research bench to clinical practice. J Androl. 2002; 23:737-52.

21. Agarwal A. Role of oxidative stress in male infertility and antioxidant supplementation. US Kidney \& Urological Disease. 2005; 8:122-5.

22. May-Panloup P, Chretien MF, Savagner F, Vasseur C, Jean M, Malthiery Y, et al. Increased sperm mitochondrial DNA content in male infertility. Hum Reprod. 2003; $18: 550-6$.

23. Aitken R, Krausz C. Oxidative stress, DNA damage and the Y chromosome. Reproduction. 2001;122: 497-506.

24. Agarwal A, Said TM. Oxidative stress, DNA damage and apoptosis in male infertility: a clinical approach. BJU Int. 2005;95:503-7.

25. Sinha HAP, Swerdoff RS. Hormonal and genetic control of germ cell apoptosis in the testis. Rev Reprod. 1999; 4: $38-47$.

26. Kocak I, Dundar M, Hekimgil M, Okyay P. Assessment of germ cell apoptosis in cryptorchid rats. Asian J Androl. 2002;4:183-6. 